\title{
Translation and validation of the Life Satisfaction Index for Adolescents scale with neuromuscular disorders: LSI-A Brazil
}

\author{
Tradução e validação da escala de qualidade de vida para adolescentes com doenças \\ neuromusculares para português do Brasil: LSI-A Brasil \\ Valdecir Antonio Simon', Edmar Zanoteli', Margarete Andreozzi Vaz Pereira Simon², \\ Maria Bernadete Dutra de Resende 1 , Umbertina Conti Reed ${ }^{1}$
}

\begin{abstract}
Objective: To validate the Life Satisfaction Index for Adolescents (LSI-A) scale, parent version and patient version, for Duchenne muscular dystrophy (DMD), spinal muscular atrophy (SMA) and limb-girdle muscular dystrophy (LGMD). Methods: The parent version of the instrument was divided into Groups A, B, C and D; and the patient version, divided into B, C and D. For the statistical calculation, the following tests were used: Cronbach's $\alpha$, ICC, Pearson and the ROC Curve. Results: The parent and patient versions of the instrument are presented, with the following results in the overall score, respectively: Cronbach's $\alpha, 0.87$ and 0.89; reliability, $r 0.98$ and 0.97; reproducibility, ICC 0.69 and 0.80 ; sensitivity, 0.78 and 0.72 ; specificity, 0.5 and 0.69 ; and accuracy, $64 \%$ and $70.4 \%$. Conclusion: According to the validity and reproducibility values, the LSI-A Brazil parent and patient versions, are clinically useful to assess quality of life in DMD, SMA or LGMD and may also be useful for other neuromuscular disorders.
\end{abstract}

Keywords: validation studies; quality of life; neuromuscular disorders.

RESUMO

Objetivo: Validar a escala Life Satisfaction Index for Adolescents (LSI-A) versão pais e versão paciente para doenças neuromusculares. Método: O instrumento versão pais foi dividido nos Grupos A,B, C e D; e paciente, em B, C e D. Para cálculo estatístico utilizou-se os testes $\alpha$ de Cronbach, CIC, Pearson e Curva ROC. Resultados: Valor de Cronbach versão pais e paciente no escore geral, 0.87 e 0.89; confiabilidade,0.98 e 0.97; reprodutibilidade,entre 0.59 e 0.69 e, entre 0.58 e 0.80; sensibilidade, 0.78 e 0.72; especificidade, 0.5 e 0.69 ; e acurácia, $64 \%$ e $70.4 \%$ respectivamente. Conclusão: Conforme a validade e reprodutibilidade, o LSI-A Brasil versão pais e paciente é útil clinicamente para avaliar a Qualidade de Vida da Distrofia Muscular de Duchenne, Amiotrofia Espinhal Progressiva ou Distrofia Muscular tipo Cinturas e pode ser usado para outras doenças neuromusculares.

Palavras-chave: estudos de validação; qualidade de vida; doenças neuromusculares.

The importance of quantifying the quality of life of subjects with neuromuscular disorders (NMD) by use of appropriate instruments is a relevant health issue because of the lack of specific questionnaires. This study dealt with the translation and validation of a questionnaire for NMD patients. In this study, three NMDs were considered: two dystrophies and one atrophy: Duchenne muscular dystrophy (DMD), limb-girdle muscular dystrophy (LGMD) and spinal muscular atrophy (SMA), respectively. The dystrophies are characterized by irreversible degeneration of muscular fibers, which leads to muscular weakness and motor disability, originating from mutations in different genes ${ }^{1}$. The atrophy is characterized by degeneration of the spinal cord motor neurons, i.e., secondary muscular atrophy ${ }^{1}$.

There is scientific consensus that the health-related quality of life (HRQOL) involves subjective and multidimensional values, either negative or positive, according to individual perception and expectation, and to the cultural influence of the individual ${ }^{2}$. The quality of life can be reported by the child or by a related caregiver ${ }^{3}$ to augment the HRQOL instruments,

'Universidade de São Paulo, Faculdade de Medicina, Departamento de Neurologia, São Paulo SP, Brasil;

${ }^{2}$ Universidade de São Paulo, Faculdade de Medicina, Hospital das Clínicas, Instituto da Criança, Departamento de Distúrbios de Aprendizagem, São Paulo SP, Brasil. Correspondence: Valdecir Antonio Simon;Av. Dr. Eneas de Carvalho Aguiar, 255 / sala 5083; 05403-000 São Paulo SP, Brasil; E-mail:valdecirsimon@usp.br Conflict of interest: There is no conflict of interest to declare.

Support: Higher Education Personnel Improvement Coordination (Coordenação de Aperfeiçoamento de Pessoal de Nivel Superior - CAPES). It was carried out in the Department of Neurology, School of Medicine, University of São Paulo and in the João Pinheiro School.

Received 06 December 2016; Received in final form 02 April 2017; Accepted 11 May 2017. 
which complement the clinical assessment of the patient and the conducting of clinical tests ${ }^{4}$, and to assess the magnitude of longitudinal changes and, mainly, to evaluate the impact of certain interventions with the purpose of modifying the symptoms and the functionality of the patient through time ${ }^{5}$.

For this relevant task, the Life Satisfaction Index for Adolescents (LSI-A) scale was selected as more effective in assessing the HRQOL of patients with NMDs, as it is broader than the usual emphasis on psychosocial, behavioral, psychological and educational aspects of HRQOL, and includes a few items that deal with physical aspects that contribute to the precise establishment of the HRQOL. As already mentioned, HRQOL depends on the patient's perception of their life domains. This analysis was a longitudinal study applied to 95 children diagnosed with DMD 6 .

According to authors Reid and Renwick ${ }^{7}$, the LSI-A aims to assess the HRQOL perception of adolescents, between the ages of 12 and 19 years old, diagnosed with $\mathrm{DMD}^{7}$. The authors ${ }^{7}$ considered that further studies may expand the application of the LSI-A to the other NMDs. Parrish. ${ }^{8}$ also verified, with psychometric properties, that the LSI-A instrument was adequate for the expansion to other NMDs. Therefore, the goal of this study was to translate to Brazilian Portuguese, and validate, the patient version of the LSI-A scale and to create and validate a parent version, for patients with DMD. As well, the LSI-A was expanded to include LGMD and SMA. The age range of the patient version (with previous authorization by the authors) was also expanded, from the previous 12 to 19 years old, to embrace the ages eight to 18 years old. The parent version created in this study is capable of embracing children and adolescents between five and 18 years old.

As the LSI-A instrument has a high level of effectiveness in the assessment of HRQOL and, due to its importance in the neuromuscular field, this scale was validated for the Brazilian Portuguese language in this study, creating the Life Satisfation Index for Adolescents (LSI-A Brazil) parent version and patient version (Appendix).

\section{METHODS}

This study was approved by the Ethics Committee for Analysis of Research Projects (CAPPesq) of the Hospital Clinical Board, number 0505/2010. For the validation of the LSI-A Brazil instrument parent version and patient version for patients with DMD, LGMD or SMA, the patients were recruited from the Neurology Clinic of the Clinics Hospital of the University of São Paulo Medical School. The healthy group was recruited from João Pinheiro School, São Paulo, Brazil.

\section{Instrument}

The LSI-A is self-administered and is used to assess HRQOL for patients with NMDs. It broadly covers subjective and multidimensional aspects and contains 45 questions with a Likert scale ranging from 0 to 5 (with 1 meaning "fully disagree", 2 meaning "disagree", 3 meaning "neither agree nor disagree", 4 meaning "agree", 5 meaning "fully agree" and 0 meaning "not applicable"). The instrument covers five domains: general well-being, interpersonal relationship, development, personal satisfaction, leisure and recreation, with nine questions for each domain, and a higher score representing a better index ${ }^{7}$. The same characteristics made up both the parent version and patient version of the LSI-A Brazil.

\section{Participants}

This protocol included 82 participants, 43 (52.4\%) of whom were diagnosed with DMD, 18 (22\%) with LGMD, and $21(25.6 \%)$ with SMA. Their age means and standard deviation were: DMD $11.4 \pm 3.38$, LGMD $10.58 \pm 3.48$ and SMA $10.95 \pm 2.98$. The diagnoses were verified by molecular test (DMD and SMA) or by immunohistochemical analysis of dystrophin and other muscle proteins through muscle biopsy (DMD and LGMD).

The inclusion criteria for NMD patients were: individuals with a confirmed diagnosis of DMD, LGMD or SMA, between five and 18 years old; without cognitive deficit and intelligence quotient (IQ) above 80; who were reliable patients, whose parents agreed to take part in this research protocol and signed the Free and Informed Consent Form. The exclusion criteria were: patients without a confirmed diagnosis of the referred NMDs, under the age of five and above 18 years old; with a cognitive deficit and IQ below 80; who were not reliable on the scheduled days or who had interrupted clinical supervision.

The inclusion criteria of the healthy group considered healthy participants age-matched to the NMD sample ( five to 18 years old), IQ above 80, whose parents agreed to take part in this research protocol and signed the Free and Informed Consent Form.

The patients and healthy participants answered the LSI-A Brazil patient version, and the parents of these participants answered the parent version of the LSI-A Brazil questionnaire. This was part of the validation of both versions.

\section{Protocol}

The translation of the LSI-A scale into Brazilian Portuguese, the validation of the LSI-A Brazil patient version and the creation and validation of the LSI-A Brazil parent version was carried out between October 2012 and July 2013. For this process, the versions were applied by intra-observer for $33 \%$ of the participants. The average duration of the applications was seven minutes each.

The validation followed the steps proposed by Guillemin et al. ${ }^{9}: 1$ ) authorization by the authors; 2) initial translation into Portuguese; 3) cultural, conceptual, experimental and idiomatic adaptation to the target population; 4) retroversion; 5) assessment by a revision committee; and 6) pretest in two stages. The creation of the parent version occurred after the retroversion of the LSI-A Brazil patient version. 


\section{Description of the validation steps}

The process of validation of the LSI-A patient version translated to Brazilian Portuguese had the prior authorization (Step 1) of Ted Myerscough, from the Quality of Life Research Unit of the University of Toronto, Canada. The questionnaire was translated by an native English language professional translator and by a certified translator (Step 2). After the comparison of both translations, it was noted that the translation made by the English language native translator was non-literal and, therefore, culturally more appropriate, closer to colloquial language and more effective for the process of linguistic adaptation than the certified translation. The Probe ${ }^{10}$ technique was included in the third step. This technique is used to achieve a satisfactory comprehension level, which should be above $85 \%$. Its application was directed to three groups of 20 patients, in three phases. During this process, there was an improvement in the linguistic quality of the instrument through cultural adaptation using the following criteria: semantic, idiomatic, conceptual and experimental equivalences.

The Portuguese language version, resulting from the Probe technique was re-translated into the English language by a native English language translator and compared to the original (Step 4). The analysis of this retranslation allowed the verification of linguistic equivalence. After this step, the version resulting from the Probe technique was submitted for assessment by the revision committee (comprising three neuropediatricians, one pedagogue and one phonoaudiologist), which suggested some technical changes in the resultant version (Step 5).

After the LSI-A Brazil patient version reached a high, and satisfactory level of comprehension, the parent version was created through pronoun changes and semantic modification of some terms to better suit the adult profile. The parent version passed through the $5^{\text {th }}$ and $6^{\text {th }}$ steps.

Step 6 was divided into two periods: first, the reapplication of the Probe technique in order to achieve the satisfactory comprehension level for the patient version $(n=18)$ and the parent version $(\mathrm{n}=18)$ after the changes suggested by the revision committee; secondly, there was application of the final version of the LSI-A Brazil parent version and patient version for psychometric evaluation, obtained by statistical calculation of the quantification of the HRQOL of the patients. Note that the serial applications did not influence the result because the questionnaire is appropriate for longitudinal studies. The psychometric evaluation was distributed accordingly: internal consistency (reliability of questions), parent version $\mathrm{n}=15$ and patient version $\mathrm{n}=21$; external consistency (interobserver correlation), parent version $n=22$ and patient version $\mathrm{n}=32$; external consistency (test-retest reproducibility - twice with an interval of three months), parent version $n=05$ and patient version $n=10$; sensitivity and specificity, parent version $\mathrm{n}=15$ and patient version $\mathrm{n}=32$.

For the cutoff point, the Receiver Operating Characteristic (ROC) Curve test was applied to healthy participants and to children and adolescents with DMD, LGMD or SMA, with 82 patients in total. The same was carried out with the parent version, which was applied to the healthy children's parents $(\mathrm{n}=82)$ and the patients' parents $(\mathrm{n}=82)$.

To establish the cutoff for age range, the patients with DMD, LGMD and SMA were distributed equally into four age groups: Group A, $\mathrm{n}=19,5-7$ years old; Group B, $\mathrm{n}=21,8-10$ years old; Group C, $\mathrm{n}=20$, 11-13 years old; Group D, $\mathrm{n}=22$, 14-18 years old. The parent version was divided into A, B, C, and D groups, while the patient version was divided into B, C, and D groups.

\section{Statistics}

For the validation of the questionnaire, the gold standard was adopted as a series of tests that expressed the accuracy value. Firstly, the statistical description - mean and standard deviation of healthy subjects and those with NMDs - was calculated. The calculation of internal consistency, item reliability, was made using the Cronbach's alpha Coefficient test. For the calculation of external consistency - the inter-observer correlation - Pearson's Linear Correlation (r) test was applied ${ }^{11}$. Reproducibility was analyzed through the scores of two applications, with an interval of three months, using the Intraclass Correlation Coefficient test (ICC) $)^{12,13}$. The ROC Curve test was used for the assessment of sensitivity, specificity, cutoff, and accuracy. For cutoff of the age category, the ROC Curve test compared patients with DMD, LGMD and SMA and the healthy group, both groups divided into their age ranges.

For the graphical analysis of the ROC Curve test, values above the curve were considered satisfactory ${ }^{14}$. The level was considered significant when $\mathrm{p}<0.5$.

The SPSS Statistics version 2.2 was used for Cronbach's alpha and the BioStat version 5.3 package for the Pearson's, ICC, and ROC Curve tests.

\section{RESULTS}

The level of comprehension reached via the final Probe technique was $97 \%$ for the parent version and $95 \%$ for the patient version, which is above the minimum of $85 \%$ required. The averages and standard deviations of the domains can be seen in Table 1.

Cronbach's alpha test was used to assess the reliability of the items in the LSI-A Brazil parent version and patient version and it showed a overall score of $\alpha=0.87$ for the parent version and $\alpha=0.89$ for the patient version. These values and the values of the other domains, the values of which guarantee moderate/high psychometric reliability, are shown in Table 2.

Pearson's Linear Correlation Test for the LSI-A Brazil parent version was $r=0.98$ and for the patient version was $r=0.97$ in the overall score. The remaining domains are shown in Table 2. There were significant differences in all domains, with values of $\mathrm{p}<0.0001$. The test, which had a confidence interval of $95 \%$, indicated a strong correlation between parent and patient participants and the inter-observer. 


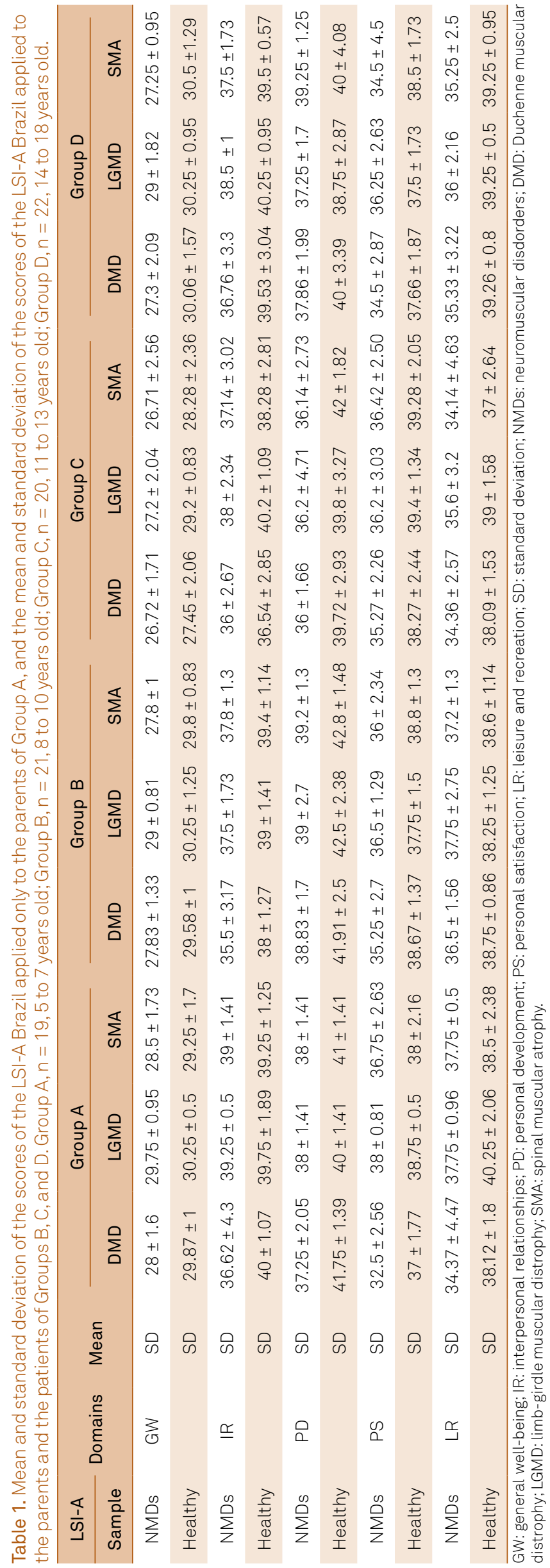

The reproducibility data for the LSI-A Brazil were assessed through the ICC test. The patient version showed ICC values ranging from 0.58 and 0.80 ; the parent version showed ICC values from 0.59 and 0.69. All domains showed a significant difference. Both versions indicated a satisfactory reproducibility (Table 3 ).

The ROC Curve test showed satisfactory results above the diagonal line. Due to significant differences in all domains for both versions as a result of its application for groups with DMD, LGMD and SMA, and for the healthy group, the LSI-A Brazil parent version overall score showed the following results: sensitivity $=0.78$, specificity $=0.5$, cutoff $=35.8$ and accuracy $=70.35 \%$; and the LSI-A Brazil patient version overall score showed sensitivity $=0.72$, specificity $=0.69$, cutoff $=37$ and accuracy $=70.4 \%$. The remaining results of the different domains are presented in Table 4 and Figures A and B. The cutoff value of the LSI-A Brazil parent version, and the patient version, was standardized according to age groups (Table 5). Note: as the variance was not significant between the two versions in all domains, the cutoff remains the same for both.

\section{DISCUSSION}

According to the authors, the original LSI-A is promising ${ }^{15}$, since it obtained satisfactory psychometric data and proved sensitive to the perception of changes in the domains of HRQOL of patients with $\mathrm{DMD}^{16}$; that is, even a year after its application, the instrument showed reliable results due to its good replicability $^{17}$. Equally, in this study, the validation of the LSI-A Brazil

Table 2. Cronbach alpha and Pearson's test of the LSI-A Brazil parent version and patient version.

\begin{tabular}{|c|c|c|c|c|c|}
\hline LSI-A & Item & Parent & Patient & Parent & Patient \\
\hline Domains & $\mathrm{n}$ & Cronbach's $\alpha$ & Cronbach's $\alpha$ & r Pearson & r Pearson \\
\hline OS & 45 & 0.87 & 0.89 & 0.98 & 0.97 \\
\hline GW & 9 & 0.65 & 0.75 & 0.89 & 0.84 \\
\hline IR & 9 & 0.65 & 0.73 & 0.96 & 0.96 \\
\hline PD & 9 & 0.65 & 0.78 & 0.93 & 0.96 \\
\hline PS & 9 & 0.71 & 0.70 & 0.98 & 0.97 \\
\hline LR & 9 & 0.78 & 0.80 & 0.96 & 0.98 \\
\hline
\end{tabular}

OS: overall score; GW: general well-being; IR: interpersonal relationships; PD: personal development; PS: personal satisfaction; LR: leisure and recreation; Confidence interval: $95 \%$.

Table 3. Intraclass correlation test of the LSI-A Brazil parent version and patient version applied at two different times.

\begin{tabular}{lccccc}
\hline ICC & GW & IR & PD & PS & LR \\
\hline Parent ICC & 0.59 & 0.58 & 0.46 & 0.56 & 0.69 \\
$\quad$ Parent test power & 0.08 & 0.08 & 0.14 & 0.09 & 0.04 \\
\hline Conclusion & MR & MR & MR & MR & MR \\
Patient ICC & 0.78 & 0.58 & 0.72 & 0.67 & 0.8 \\
\multicolumn{1}{c}{ Patient test power } & 0.001 & 0.024 & 0.004 & 0.008 & 0.001 \\
\multicolumn{1}{c}{ Conclusion } & ER & MR & MR & MR & ER \\
\hline ICC: intraclass correlation; GW: general & well-being; & IR: interpersonal \\
relationships; PD: personal development; PS: personal satisfaction; LR: leisure \\
and recreation; MR: moderate to good replicability; ER: excellent replicability.
\end{tabular}


showed significant values for all domains in the three NMDs, indicating that the patient version and the later-created parent version presented with satisfactory indexes, indicating its efficacy and trustworthiness in capturing the perception of HRQOL of patients between five and 18 years old with DMD, LGMD and SMA. Note that the age range of the NMD patients was expanded from the original version. Due to the validation process that used a cross-cultural adaptation strategy, also adopted by other studies ${ }^{18,19}$, the resultant versions had

Table 4. Values of the ROC Curve of the LSI-A parent version and patient version.

\begin{tabular}{|c|c|c|c|c|}
\hline ROC curve & Sensitivity & pecificity & Distance & Accuracy \\
\hline \multicolumn{5}{|l|}{ Parents } \\
\hline Overall Score & 0.78 & 0.5 & 0.46 & $64 \%$ \\
\hline $\begin{array}{l}\text { General } \\
\text { Well-being }\end{array}$ & 0.73 & 0.68 & 0.42 & $70.5 \%$ \\
\hline $\begin{array}{l}\text { Interpersonal } \\
\text { Relationships }\end{array}$ & 0.56 & 0.68 & 0.53 & $62.6 \%$ \\
\hline $\begin{array}{l}\text { Personal } \\
\text { Development }\end{array}$ & 0.86 & 0.68 & 0.34 & $77 \%$ \\
\hline $\begin{array}{l}\text { Personal } \\
\text { Satisfaction }\end{array}$ & 0.59 & 0.77 & 0.46 & $68 \%$ \\
\hline $\begin{array}{l}\text { Leisure and } \\
\text { Recreation }\end{array}$ & 0.59 & 0.77 & 0.47 & $68.2 \%$ \\
\hline \multicolumn{5}{|l|}{ Patients } \\
\hline Overall Score & 0.72 & 0.69 & 0.42 & $70.4 \%$ \\
\hline $\begin{array}{l}\text { General } \\
\text { Well-being }\end{array}$ & 0.72 & 0.6 & 0.5 & $65.7 \%$ \\
\hline $\begin{array}{l}\text { Interpersonal } \\
\text { Relationships }\end{array}$ & 0.56 & 0.69 & 0.53 & $62.5 \%$ \\
\hline $\begin{array}{l}\text { Personal } \\
\text { Satisfaction }\end{array}$ & 0.68 & 0.63 & 0.48 & $65.7 \%$ \\
\hline $\begin{array}{l}\text { Leisure and } \\
\text { Recreation }\end{array}$ & 0.53 & 0.66 & 0.58 & $59.4 \%$ \\
\hline
\end{tabular}

A

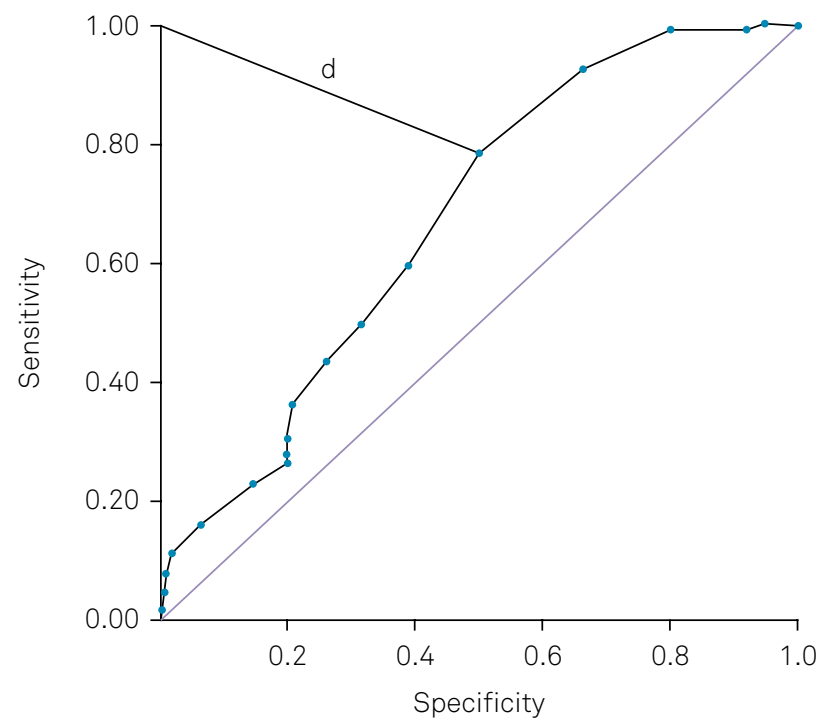

accessible language and easy comprehension and application. Therefore, the LSI-A Brazil is capable of quantifying the HRQOL with precision. Beyond this, it preserves the subjective content, psychological and social aspects, as well as physi$\mathrm{cal}^{20,21}$ features, which makes it a tool with positive differences above other scales.

The items in this questionnaire obtained high reliability of internal consistency across the application of Cronbach's alpha in both versions; the same occurred in the original patient version? ${ }^{7}$ There was proximity of values in both studies, which reinforces the quality of this validation.

The external consistency in the original patient version, measured through Pearson's Linear Correlation Test, was considered moderate ${ }^{7}$. This study showed, in both patient version and parent version, high correlation values with a significance of $p<0.0001$ in all domains. The statistical data revealed the concordance between observers during the interviews, which gave greater psychometric quality to this validation.

The external consistency was shown in the ICC. By test-retest, the LSI-A Brazil reached satisfactory values regarding replicability, indicating that it qualifies as reproducible. The values of the ICC test obtained in this study were moderate, that is, both versions of the questionnaire retained the same reference values in applications under different circumstances and places without changes of results, which made it trustworthy. However, the values resulting from the application may vary in relation to the clinical characteristics of each situation.

The gold standard originated from the application of many psychometric tests used in this validation, indicating the accuracy of the LSI-A Brazil, also shown in the ROC Curve test, which is used to assess the quality of a given clinical test ${ }^{22,23}$.

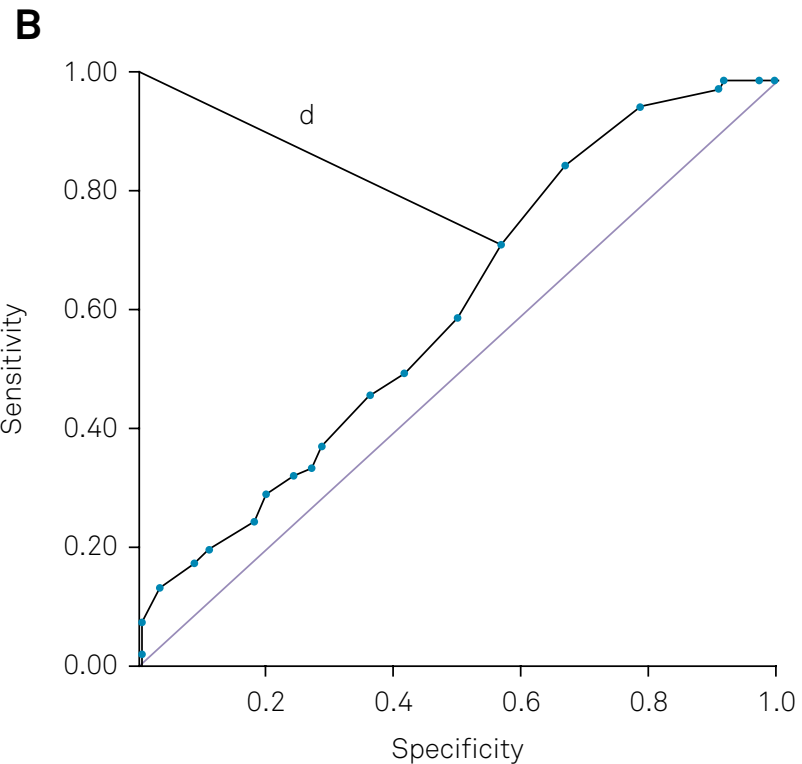

Figure. A. The ROC Curve of the Overall Score of LSI-A Brazil parent version. B. The ROC Curve of the Overall Score of LSI-A Brazil patient version 
Table 5. Cutoff of age group of the LSI-A Brazil parent version and patient version.

\begin{tabular}{lcc}
\hline LSI- A & Age / years old & Cutoff \\
\hline DMD & $5-7$ & 35 \\
& $8-10$ & 37 \\
& $11-13$ & 36 \\
LGMD & $14-18$ & 37 \\
& $5-7$ & 38 \\
& $8-10$ & 38 \\
& $11-13$ & 38 \\
SMA & $14-18$ & 38 \\
& $5-7$ & 38 \\
& $8-10$ & 38 \\
& $11-13$ & 36 \\
\hline
\end{tabular}

Receiver operating characteristic - Curve ROC. Confidence interval: $95 \%$. Group A, $n=19,5$ to 7 years old; Group B, $n=21,8$ to 10 years old; Group C, $n=20,11$ to 13 years old; Group D, $n=22,14$ to 18 years old. DMD: Duchenne muscular distrophy; LGMD: limb-girdle muscular dystrophy; SMA: spinal muscular atrophy.

This indicated, in both versions, significant sensitivity and specificity above the reference line. The accuracy, remaining above $60 \%$, also indicated a good measurement of what the study aimed for with the instrument - guaranteeing good efficacy ${ }^{24}$.
The ROC Curve test also established the cutoff value of the instrument, which is capable of indicating changes in clinical practice and serves as a reference for routine applications ${ }^{25}$. Through standardization of the cutoff related to age range and pathology, it is possible to assess the HRQOL with greater precision, given that values higher than the cutoff value indicate an increase in $\mathrm{HRQOL}^{2,26}$.

According to psychometric data for internal and external consistency (reliability and reproducibility), sensitivity, specificity, and accuracy, the LSI-A Brazil parent version is useful to assess the quality of life of patients between five and 18 years old and the patient version is also helpful for patients between eight and 18 years old for DMD, LGMD or SMA. The LSI-A Brazil can easily be expanded to evaluate the HRQOL of other neuromuscular disorders, but further studies are needed to confirm that.

\section{Acknowledgement}

We thank all patients, students, parents, teachers and all individuals who participated in this study.

\section{References}

1. Reed UC. [Neuromuscular disorders]

J Pediatr (Rio J). 2002;78(1 Suppl 1):89-103. https://doi.org/10.1590/S0021-7557200200070001

2. Bullinger M, Anderson R, Cella D, Aaronson N. Developing and evaluating cross-cultural instruments from minimum requirements to optimal models. Qual Life Res. 1993;2(6):451-9. https://doi.org/10.1007/BF00422219

3. Eiser C, Morse R. A review of measures of quality of life for children with chronic illness. Arch Dis Child. 2001;84(3):205-11. https://doi.org/10.1136/adc.84.3.205

4. Gill T, Feinstein AR. A critical appraisal of the quality of quality-of-life measurements. JAMA. 1994;272(8):619-25. https://doi.org/10.1001/jama.1994.03520080061045

5. Guyatt GH, Feeny DH, Patrick DL. Measuring health-related quality of life. Ann Intern Med. 1993;118(8):622-9. https://doi.org/10.7326/0003-4819-118-8-199304150-00009

6. Simon VA, Resende MBD, Simon MA, Zanoteli E, Reed UC. Duchenne muscular dystrophy: quality of life among 95 patients evaluated using the Life Satisfaction Index for Adolescents. Arq Neuropsiquiatr. 2011;69(1):19-22. https://doi.org/10.1590/S0004-282X2011000100005

7. Reid DT, Renwick RM. Preliminary validation of a new instrument to measure life satisfaction in adolescents with neuromuscular disorders. Int J Rehabil Res. 1994;17(2):184-8. https://doi.org/10.1097/00004356-199406000-00009

8. Parrish RK 2nd. Visual impairment, visual functioning, and quality of life assessments in patients with glaucoma. Trans Am Ophthalmol Soc. 1996;94:919-1028.

9. Guillemin F, Bombardier C, Beaton D. Cross-cultural adaptation of health-related quality of life measures: literature review and proposed guidelines. J Clin Epidemiol. 1993;46(12):1417-32. https://doi.org/10.1016/0895-4356(93)90142-N
10. Clark P, Lavielle P, Martínez H. Learning from pain scales: patient perspective. J Rheumatol. 2003;30(7):1584-8.

11. Pearson K, Fisher R, Inman HF. Karl Pearson and R. A. Fisher on statistical tests: a 1935 exchange from nature. Am Stat. 1994;48(1):2-11. https://doi.org/10.2307/2685077

12. Shrout PE, Fleiss JL. Intraclass correlations: uses in assessing rater reliability. Psychol Bull 1979;86(2):420-8. https://doi.org/10.1037/0033-2909.86.2.420

13. Fayers PM, Machin D. Quality of life: assessment, analysis and interpretation. New York: Wiley; 2000.

14. Cronbach LJ. Coefficient alpha and the internal structure of tests. Psychometrika. 1951;16(3):297-334. https://doi.org/10.1007/BF02310555

15. Melo ELA, Valdés MTM, Pinto JMS. Qualidade de vida em crianças e adolescentes com distrofia muscular de Duchenne. Pediatria (São Paulo). 2005;27(1):28-37.

16. Solans M, Pane S, Estrada MD, Serra-Sutton V, Berra S, Herdman $\mathrm{M}$ et al. health-related quality of life measurement in children and adolescents: a systematic review of generic and disease-specific instruments. Value Health. 2008;11(4):742-64. https://doi.org/10.1111/j.1524-4733.2007.00293.x

17. McDougall J, Servais M, Sommerfreund J, Rosen E, Gillett J, Gray J et al. An evaluation of the paediatric acquired brain injury community outreach programme (PABICOP). Brain Inj. 2006;20(11):1189-205. https://doi.org/10.1080/02699050600975541

18. Barbosa TS, Tureli MC, Gavião MB. Validity and reability of the Child Perceptions Questionnaires applied in Brazilian children. BMC Oral Health. 2009;9(1):13. https://doi.org/10.1186/1472-6831-9-13

19. Bandeira M, Calzavara MGP, Costa CS, Cesari L. Avaliação de serviços de saúde mental: adaptação transcultural de uma medida da percepção dos usuários sobre os resultados do tratamento. J Bras Psiquiatr. 2009;58(2):107-14. https://doi.org/10.1590/S0047-20852009000200007 
20. Boström K, Ahlström G. Quality of life in patients with muscular dystrophy and their next of kin. Int J Rehabil Res. 2005;28(2):103-9. https://doi.org/10.1097/00004356-200506000-00002

21. Boyer F, Drame M, Morrone I, Novella JL. Factors relating to carer burden for families of persons with muscular dystrophy. J Rehabil Med. 2006;38(5):309-15. https://doi.org/10.1080/16501970600731578

22. Zhou XH, Obuchowski NA, McClish DK. Statistical methods in diagnostic medicine. New York: Wiley-Interscience; 2002.

23. Silva AC, Carvalho PCP, Gattass M. Diagnosis of solitary lung nodule using texture and geometry in computerized tomography images: preliminary results. IEEE Latin America Transactions. 2004;2(2):75-80. https://doi.org/10.1109/TLA.2004.1468623

24. Sabbatini RME. Um programa para o cálculo da acurácia, especificidade e sensibilidade de testes médicos. Revista Informédica. 1995;2(12):19-21.

25. Heneghan C, Badenoch D. Ferramentas para medicina baseada em evidências. 2a ed. Porto Alegre: Artmed; 2007.

26. Yamaguchi N, Poudel KC, Poudel-Tandukar K, Shakya D, Ravens-Sieberer U, Jimba M. Reliability and validity of a Nepalese version of the Kidd-KINDL in adolescents. Biosci Trends. 2010;4(4)4:178-85. 


\section{APPENDIX}

Qualidade de Vida para crianças e adolescentes com doenças Neuromusculares - LSI-A Neuromuscular Brasil Distrofias Musculares de Duchenne e de Cinturas e Amiotrofia Espinhal Progressiva

\section{Versão Pais}

Idade 5 a 18 anos

\section{Instruções}

Neste questionário lhe pedem que responda a várias declarações, as quais tratam do grau de satisfação da vida se seu filho/a. Cada declaração é seguida por ícones de avaliação. Leia cada declaração cuidadosamente, então circule o número correspondente ao ícone de avaliação que melhor descreve o quanto você concorda ou discorda com a declaração à respeito de seu filho/a.

Por favor, leia o exemplo abaixo antes de você começar.

Exemplo:

Meu filho/a tem bastante energia.

\begin{tabular}{lllll}
\hline Discordo Plenamente Discordo Não concordo Nem discordo Concordo Concordo Plenamente Não aplicável \\
\hline
\end{tabular}

Se você concordar com esta declaração, você marcará um X no número 4. Se você discordar plenamente, você assinalará um X no número 1, e assim por diante.

\section{LEIA CADA QUESTÃO E MARQUE SOMENTE UMA RESPOSTA PARA CADA ITEM.}

As informações que você der ficarão em sigilo.

LSI-A Neuromuscular Brasil versão pais

\begin{tabular}{|c|c|c|c|c|c|c|}
\hline $\begin{array}{l}\text { Considerando a última semana, responda } \\
\qquad \text { Meu filho (a) ... }\end{array}$ & $\begin{array}{c}\text { Discordo } \\
\text { Plenamente }\end{array}$ & Discordo & $\begin{array}{l}\text { Não } \\
\text { concordo } \\
\text { nem } \\
\text { discordo }\end{array}$ & Concordo & $\begin{array}{l}\text { Concordo } \\
\text { Plenamente }\end{array}$ & $\begin{array}{l}\text { Não } \\
\text { Aplicável }\end{array}$ \\
\hline 1.Tem bastante energia & 1 & 2 & 3 & 4 & 5 & 0 \\
\hline 2. Muitas vezes se sente mal & 1 & 2 & 3 & 4 & 5 & 0 \\
\hline 3. Está feliz com sua aparência & 1 & 2 & 3 & 4 & 5 & 0 \\
\hline 4. Tem amigos para conversar & 1 & 2 & 3 & 4 & 5 & 0 \\
\hline 5. Está feliz com seus familiares & 1 & 2 & 3 & 4 & 5 & 0 \\
\hline 6. Não gosta de pedir ajuda às pessoas & 1 & 2 & 3 & 4 & 5 & 0 \\
\hline 7. Gosta da escola & 1 & 2 & 3 & 4 & 5 & 0 \\
\hline 8. Gosta do que faz quando não está na escola & 1 & 2 & 3 & 4 & 5 & 0 \\
\hline 9. Acredita que pode melhorar o mundo & 1 & 2 & 3 & 4 & 5 & 0 \\
\hline 10. Está feliz com sua vida & 1 & 2 & 3 & 4 & 5 & 0 \\
\hline 11. Gosta de si mesmo & 1 & 2 & 3 & 4 & 5 & 0 \\
\hline $\begin{array}{l}\text { 12. Quando as coisas vão mal,acha que podem } \\
\text { melhorar }\end{array}$ & 1 & 2 & 3 & 4 & 5 & 0 \\
\hline 13. Está feliz com tudo o que fez na sua vida até agora & 1 & 2 & 3 & 4 & 5 & 0 \\
\hline 14. Gostaria de mais tempo livre & 1 & 2 & 3 & 4 & 5 & 0 \\
\hline 15. Quando está entediado, sabe arrumar o que fazer & 1 & 2 & 3 & 4 & 5 & 0 \\
\hline 16. Tem tempo livre para fazer o que quer & 1 & 2 & 3 & 4 & 5 & 0 \\
\hline 17. Está feliz com os momentos de lazer que ele têm & 1 & 2 & 3 & 4 & 5 & 0 \\
\hline 18. Ir ao médico o atrapalha no que quer fazer & 1 & 2 & 3 & 4 & 5 & 0 \\
\hline $\begin{array}{l}\text { 19. Fala que cadeira de rodas não o atrapalha para } \\
\text { fazer o que quer }\end{array}$ & 1 & 2 & 3 & 4 & 5 & 0 \\
\hline 20. Está feliz com seus amigos & 1 & 2 & 3 & 4 & 5 & 0 \\
\hline 21. Acha que nós o apoiamos em suas decisões & 1 & 2 & 3 & 4 & 5 & 0 \\
\hline $\begin{array}{l}\text { 22. Está feliz com as chances que tem para tentar } \\
\text { fazer coisas novas }\end{array}$ & 1 & 2 & 3 & 4 & 5 & 0 \\
\hline 23. Se acalma quando se assusta & 1 & 2 & 3 & 4 & 5 & 0 \\
\hline
\end{tabular}




\begin{tabular}{|c|c|c|c|c|c|c|}
\hline 24. Consegue esperar pelo dia de amanhã & 1 & 2 & 3 & 4 & 5 & 0 \\
\hline 25. Não tem tempo para se divertir & 1 & 2 & 3 & 4 & 5 & 0 \\
\hline $\begin{array}{l}\text { 26. Fica triste por não poder fazer o que quer em } \\
\text { seu tempo livre }\end{array}$ & 1 & 2 & 3 & 4 & 5 & 0 \\
\hline 27. Fica chateado facilmente & 1 & 2 & 3 & 4 & 5 & 0 \\
\hline $\begin{array}{l}\text { 28. Sente que sua situação física o atrapalha } \\
\text { naquilo que faz }\end{array}$ & 1 & 2 & 3 & 4 & 5 & 0 \\
\hline $\begin{array}{l}\text { 29. Durante as aulas, seus professores o deixam } \\
\text { falar o que acha }\end{array}$ & 1 & 2 & 3 & 4 & 5 & 0 \\
\hline $\begin{array}{l}\text { 30. Pensa que as pessoas que cuidam de sua } \\
\text { saúde (médicos, enfermeiras, fisioterapeutas etc) o } \\
\text { entendem }\end{array}$ & 1 & 2 & 3 & 4 & 5 & 0 \\
\hline 31. Tem chance de ajudar os outros & 1 & 2 & 3 & 4 & 5 & 0 \\
\hline $\begin{array}{l}\text { 32. Procura informações sobre o que cada } \\
\text { profissão faz }\end{array}$ & 1 & 2 & 3 & 4 & 5 & 0 \\
\hline 33. Pensa que ele nunca será quem ele gostaria de ser & 1 & 2 & 3 & 4 & 5 & 0 \\
\hline 34. Tem planos para o futuro & 1 & 2 & 3 & 4 & 5 & 0 \\
\hline $\begin{array}{l}\text { 35. Pensa que a escola é importante para ele ter } \\
\text { uma profissão }\end{array}$ & 1 & 2 & 3 & 4 & 5 & 0 \\
\hline 36. Está feliz com sua saúde & 1 & 2 & 3 & 4 & 5 & 0 \\
\hline 37. Tem dificuldade para fazer o que quer & 1 & 2 & 3 & 4 & 5 & 0 \\
\hline 38. Diverte se com a nossa família & 1 & 2 & 3 & 4 & 5 & 0 \\
\hline 39. Está feliz com as chances que tem para passear & 1 & 2 & 3 & 4 & 5 & 0 \\
\hline 40. Acha difícil relaxar & 1 & 2 & 3 & 4 & 5 & 0 \\
\hline 41. Se sente bem entre as pessoas & 1 & 2 & 3 & 4 & 5 & 0 \\
\hline $\begin{array}{l}\text { 42. Está feliz com a amizade que tem com as } \\
\text { meninas ou com os meninos }\end{array}$ & 1 & 2 & 3 & 4 & 5 & 0 \\
\hline $\begin{array}{l}\text { 43. Acha que nós nos esforçamos para entender } \\
\text { seus sentimentos }\end{array}$ & 1 & 2 & 3 & 4 & 5 & 0 \\
\hline 44. Faz coisas que ele se sente orgulhoso de fazer & 1 & 2 & 3 & 4 & 5 & 0 \\
\hline 45. Sabe o que quer ser quando crescer & 1 & 2 & 3 & 4 & 5 & 0 \\
\hline
\end{tabular}

\section{Qualidade de Vida para crianças e adolescentes com doenças Neuromusculares - LSI-A Neuromuscular Brasil Distrofias Musculares de Duchenne e de Cinturas e Amiotrofia Espinhal Progressiva}

\section{Versão Paciente}

Idade 8 a 18 anos

\section{Instruções}

Neste questionário lhe pedem que responda a várias declarações, as quais tratam do grau de satisfação de vida. Cada declaração é seguida por ícones de avaliação. Leia cada declaração cuidadosamente, então circule o número correspondente ao ícone de avaliação que melhor descreve o quanto você concorda ou discorda com a declaração.

Por favor, leia o exemplo abaixo antes de você começar.

Exemplo:

Tenho bastante energia.

\begin{tabular}{llll}
\hline Discordo Plenamente Discordo Não concordo Nem discordo Concordo Concordo Plenamente Não aplicável \\
\hline
\end{tabular}

Se você concordar com esta declaração, você marcará um X no número 4. Se você discordar plenamente, você assinalará um X no número 1, e assim por diante.

\section{LEIA CADA QUESTÃO E MARQUE SOMENTE UMA RESPOSTA PARA CADA ITEM.}

As informações que você der ficarão em sigilo. 
LSI-A Neuromuscular Brasil versão paciente

\begin{tabular}{|c|c|c|c|c|c|c|}
\hline $\begin{array}{l}\text { Considerando a última semana, responda } \\
\qquad \text { Eu... }\end{array}$ & $\begin{array}{c}\text { Discordo } \\
\text { Plenamente }\end{array}$ & Discordo & $\begin{array}{l}\text { Não } \\
\text { Concordo } \\
\text { nem } \\
\text { Discordo }\end{array}$ & Concordo & $\begin{array}{c}\text { Concordo } \\
\text { Plenamente }\end{array}$ & $\begin{array}{c}\text { Não } \\
\text { Aplicável }\end{array}$ \\
\hline 1. Tenho bastante energia & 1 & 2 & 3 & 4 & 5 & 0 \\
\hline 2. Muitas vezes eu me sinto mal & 1 & 2 & 3 & 4 & 5 & 0 \\
\hline 3. Estou feliz com minha aparência & 1 & 2 & 3 & 4 & 5 & 0 \\
\hline 4. Tenho amigos para conversar & 1 & 2 & 3 & 4 & 5 & 0 \\
\hline 5. Estou feliz com minha família & 1 & 2 & 3 & 4 & 5 & 0 \\
\hline 6. Não gosto de pedir ajuda às pessoas & 1 & 2 & 3 & 4 & 5 & 0 \\
\hline 7. Gosto da escola & 1 & 2 & 3 & 4 & 5 & 0 \\
\hline 8. Gosto do que faço quando não estou na escola & 1 & 2 & 3 & 4 & 5 & 0 \\
\hline 9. Acredito que posso melhorar o mundo & 1 & 2 & 3 & 4 & 5 & 0 \\
\hline 10. Estou feliz com minha vida & 1 & 2 & 3 & 4 & 5 & 0 \\
\hline 11. Gosto de mim mesmo & 1 & 2 & 3 & 4 & 5 & 0 \\
\hline 12. Quando as coisas vão mal, acho que podem melhorar & 1 & 2 & 3 & 4 & 5 & 0 \\
\hline 13. Estou feliz com tudo o que fiz na minha vida até agora & 1 & 2 & 3 & 4 & 5 & 0 \\
\hline 14. Gostaria de mais tempo livre & 1 & 2 & 3 & 4 & 5 & 0 \\
\hline 15. Quando estou entediado, sei arrumar o que fazer & 1 & 2 & 3 & 4 & 5 & 0 \\
\hline 16. Tenho tempo livre para fazer o que quero & 1 & 2 & 3 & 4 & 5 & 0 \\
\hline 17. Estou feliz com os momentos de lazer que tenho & 1 & 2 & 3 & 4 & 5 & 0 \\
\hline 18. Ir ao médico me atrapalha para fazer o que quero & 1 & 2 & 3 & 4 & 5 & 0 \\
\hline $\begin{array}{l}\text { 19. Usar cadeira de rodas não me atrapalha para eu fazer o } \\
\text { que quero }\end{array}$ & 1 & 2 & 3 & 4 & 5 & 0 \\
\hline 20. Estou feliz com meus amigos & 1 & 2 & 3 & 4 & 5 & 0 \\
\hline 21. Acho que meus pais me apoiam em minhas decisões & 1 & 2 & 3 & 4 & 5 & 0 \\
\hline $\begin{array}{l}\text { 22. Estou feliz com as chances que tenho para tentar } \\
\text { fazer coisas novas }\end{array}$ & 1 & 2 & 3 & 4 & 5 & 0 \\
\hline 23. Consigo me acalmar após ter me assustado & 1 & 2 & 3 & 4 & 5 & 0 \\
\hline 24. Consigo esperar pelo dia de amanhã & 1 & 2 & 3 & 4 & 5 & 0 \\
\hline 25. Não tenho tempo para me divertir & 1 & 2 & 3 & 4 & 5 & 0 \\
\hline $\begin{array}{l}\text { 26. Fico triste por não poder fazer o que quero em meu } \\
\text { tempo livre }\end{array}$ & 1 & 2 & 3 & 4 & 5 & 0 \\
\hline 27. Fico chateado facilmente & 1 & 2 & 3 & 4 & 5 & 0 \\
\hline $\begin{array}{l}\text { 28. Sinto que minha situação física me atrapalha naquilo } \\
\text { que faço }\end{array}$ & 1 & 2 & 3 & 4 & 5 & 0 \\
\hline $\begin{array}{l}\text { 29. Tenho professores que me deixam falar o que eu } \\
\text { acho nas aulas }\end{array}$ & 1 & 2 & 3 & 4 & 5 & 0 \\
\hline $\begin{array}{l}\text { 30. Penso que as pessoas que cuidam de minha } \\
\text { saúde (médicos, enfermeiras, fisioterapeutas etc) me } \\
\text { entendem }\end{array}$ & 1 & 2 & 3 & 4 & 5 & 0 \\
\hline 31. Tenho chance de ajudar os outros & 1 & 2 & 3 & 4 & 5 & 0 \\
\hline 32. Procuro informações sobre o que cada profissão faz & 1 & 2 & 3 & 4 & 5 & 0 \\
\hline 33. Penso que eu nunca serei quem eu gostaria de ser & 1 & 2 & 3 & 4 & 5 & 0 \\
\hline 34. Tenho planos para o futuro & 1 & 2 & 3 & 4 & 5 & 0 \\
\hline $\begin{array}{l}\text { 35. Penso que a escola é importante para eu ter uma } \\
\text { profissão }\end{array}$ & 1 & 2 & 3 & 4 & 5 & 0 \\
\hline 36. Estou feliz com minha saúde & 1 & 2 & 3 & 4 & 5 & 0 \\
\hline 37. Tenho dificuldade para fazer o que quero fazer & 1 & 2 & 3 & 4 & 5 & 0 \\
\hline 38. Me divirto com minha família & 1 & 2 & 3 & 4 & 5 & 0 \\
\hline 39. Estou feliz com as chances que tenho para passear & 1 & 2 & 3 & 4 & 5 & 0 \\
\hline 40. Acho difícil relaxar & 1 & 2 & 3 & 4 & 5 & 0 \\
\hline 41. Me sinto bem entre as pessoas & 1 & 2 & 3 & 4 & 5 & 0 \\
\hline $\begin{array}{l}\text { 42. Estou feliz com a amizade que tenho com as meninas } \\
\text { ou com os meninos }\end{array}$ & 1 & 2 & 3 & 4 & 5 & 0 \\
\hline $\begin{array}{l}\text { 43. Acho que meus pais tentam entender meus } \\
\text { sentimentos }\end{array}$ & 1 & 2 & 3 & 4 & 5 & 0 \\
\hline $\begin{array}{l}\text { 44. Faço coisas que me deixam eu me sentir orgulhoso } \\
\text { de fazê-las }\end{array}$ & 1 & 2 & 3 & 4 & 5 & 0 \\
\hline 45. Sei o que quero ser quando crescer & 1 & 2 & 3 & 4 & 5 & 0 \\
\hline
\end{tabular}

